\title{
PENGARUH INTERNAL MARKETING TERHADAP EMPLOYEE PERFORMANCE DENGAN MARKETING ORIENTATION DAN EMPLOYEE ENGAGEMENT SEBAGAI VARIABEL INTERVENING PADA MINIMARKET INDOMARET DAN INDOMARET POINT DI SURABAYA
}

\author{
Devi Evelyn ${ }^{1}$, Diah Dharmayanti ${ }^{2}$ \\ ${ }^{1,2}$ Program Studi Manajemen Pemasaran, Fakultas Ekonomi, Universitas Kristen Petra \\ Jl. Siwalankerto 121-131, Surabaya 60236 \\ E-mail: devievelyn14@gmail.com ${ }^{1}$,diah_dharmayanti@yahoo.com²
}

\begin{abstract}
Abstrak:Perkembangan pasar modern semakin berkembang pesat, khususnya di Indonesia pada tahun 2016. Peningkatan pengguna pasar modern juga mempengaruhi para pebisnis untuk mengembangkan bisnis retail minimarket. Minimarket dikenal dengan mini pasar modern yang mengutamakan kenyamanan berbelanja dengan beberapa fasilitasnya.Hal inilah yang berdampak pada semakin tingginya persaingan untuk mempertahankan dan meningkatkan pelayanan minimarket. Penelitian ini bertujuan untuk menganalisa pengaruh dari Internal Marketing terhadap Employee Performance pada Indomaret dan indomaret Point di Surabaya dengan Marketing Orientation dan Employee Engagement sebagai variabel intervening. Penelitian ini dilaksanakan dengan menyebarkan kuisioner kepada 100 responden karyawan Indomaret dan Indomaret Point di Surabaya.Teknik analisa yang digunakan adalah teknik analisis kuantitatif dengan metode path analysis.
\end{abstract}

Kata kunci:Internal marketing, marketing orientation, employee engagement, employee performance.

\begin{abstract}
The development of modern markets is growing rapidly, especially in Indonesia in 2016. The increase in modern market users also affects the businessmen to develop the retail minimarket business. Minimarket is known for its modern mini market which prioritizes the convenience of shopping with some amenities. This has an impact on the increasing competition for maintaining and improving minimarket services.This study aims to analyze the influence of Internal Marketing on Employee Performance at Indomaret and Indomaret Point in Surabaya with Marketing Orientation and Employee Engagement as intervening variable.This study was conducted by distributing questionnaires to 45 Indomaret and Indomaret Point employees in Surabaya. Analysis technique used is quantitative analysis technique with path analysis method.
\end{abstract}

Keywords: Internal marketing, marketing orientation, employee engagement, employee performance.

\section{PENDAHULUAN}

Ekonomi global mengalami kemunduran dalam beberapa tahun terakhir telah berdampak langsung pada pendapatan konsumen, yang hasilnya menghasut penghambatan saat mengkonsumsi.Namun usaha bisnis ritel pada pasar modern berkembang semakin pesat setiap tahunnya, terutama di kategori makanan dan bahan makanan. Pada tahun 2013, hypermarket dan supermarket mencatat nilai 3.104 miliar USD dalam kategori yang disebutkan sebelumnya, dan pada tahun 2018 mereka diperkirakan akan meningkat hingga 3.857 miliar USD.

Berdasarkan peringkat CAGR, peringkat 5 teratas bisnis ritel di seluruh dunia pada 2013-2018 adalah pengecer online sebesar $12,1 \%$, toko-toko dengan $8,3 \%$, pengecer bebas bea dengan $6,4 \%$, hypermarket dan supermarket dengan $4,4 \%$ dan department store dengan 4,2\% di Meksiko. Penjualan ritel secara keseluruhan tumbuh dari 3,394.3 miliar MXN pada tahun 2008 menjadi 4,027.5 miliar pada tahun 2013. Diperkirakan bahwa pada tahun 2018, penjualan akan mencapai 5.032 miliar MXN. Hypermarket dan supermarket adalah kelompok terbesar dengan nilai penjualan antara pengecer umum di
Meksiko. Dari tahun 2008 sampai tahun 2013, kelompok ini disamakan dengan pangsa 48,3\% dari total pasar pengecer umum. Pada tahun 2013, itu mewakili pendapatan ritel dari 1,060,858.6 juta MXN dan diperkirakan meningkat menjadi 1,346,712.2 juta MXN pada tahun 2018 (PWC, 2015).

Indonesia termasuk salah satu negara yang mengikuti perkembangan era globalisasi dalam pembentukan bisnis retail pasar modern. Indonesia berada di peringkat 12 dunia dalam Indeks Pembangunan Ritel Global (GRDI) 2015 yang dirilis AT Kearney.Ini adalah tingkat pertumbuhan ritel tertinggi yang pernah dicapai Indonesia dalam indeks sejak 2001 (Dahwilani, 2015).Indonesia berada di bawah China yang menduduki posisi pertama dengan nilai penjualan US\$3.046 miliar.Negeri Panda berturutturut diikuti oleh India, Malaysia, dan Kazakhstan. Dominasi negara-negara Asia Pasifik dalam lima peringkat teratas didukung oleh besarnya jumlah penduduk. Di luar itu, berjalannya Masyarakat Ekonomi Asean (MEA) membuat prospek kawasan Asia Tenggara makin cerah dengan nilai pasar mencapai US\$2,6 triliun dan total penduduk mencapai 622 juta jiwa (Maskur, 2016). 
Perubahan metodologi 2015 ke 2016 turut membantu naiknya peringkat Indonesia tetapi A.T Keamey mengatakan penyebab utamanya adalah karena Indonesia memiliki potensi sektor ritel yang besar dan mengatakan jumlah penduduk Indonesia yang besar dan terus bertumbuhnya kelas menengah merupakan faktor penarik investor. Menurut data A.T. Kearney, Indonesia dengan populasi 256 juta jiwa memiliki total penjualan ritel US\$ 324 miliar dengan rata-rata pertumbuhan (2013-2015) sebesar 2,3 persen( (Baskoro, 2016). Pertumbuhan PDB Indonesia diperkirakan akan rebound setelah mencapai angka terendah dalam lima tahun pada awal 2015, dan melebihi pasar regional lainnya ke depan. Meskipun sedikit mengalami penurunan penjualan ritel per kapita tahun lalu, total penjualan ritel tumbuh $14,5 \%$. AT Karney mencatat pasar ritel di Indonesia saat ini mencapai USD326 miliar atau senilai Rp 4.306 triliun (Dahwilani, 2015)

Potensi bisnis minimarket Indonesia 2017 nampaknya akan lebih baik dibandingkan dengan tahun lalu. Para pelaku retail mematok pertumbuhan bisnis ritel Indonesia mencapai $12 \%$, angka ini tentu bukan sekedar isapan jempol, merunut data Aprindo pertumbuhan retail 2016 optimis berada diangka 10\% lebih baik dari 2015 yang hanya mencapai $8 \%$. Salah satu jenis usaha ritel yang masih sangat prospektif adalah adalah minimarket. Alasannya tentu karena perbaikan kondisi ekonomi yang di proyeksikan mencapai 5,3\%. Omset ritel modern nasional pada 2016 diperkirakan tumbuh mencapai 10\%. Asosiasi Pengusaha Ritel Indonesia (Aprindo) memperkirakan nilai penjualan ritel modern 2016 mencapai 200 triliun dan jika di kombinasikan dengan makanan serta minuman olahan maka secara keseluruhan total mencapai 1.630 trilliun.

Saat ini perkembangan pasar modern sudah menyebar luas hingga ke pelosok daerah. Data yang dihimpun dari Kementrian Perdagangan (Kemendag) mengungkapkan, saat ini jumlah pasar modern yang ada diseluruh Indonesia mencapai 23.000 unit.Jumlah tersebut mengalami peningkatan sebesar 14 persen dalam tiga tahun terakhir. Pasar modern ada 23.000 dan dari jumlah itu sebanyak 14.000 lebih di antaranya merupakan kelompok usaha minimarket, sedangkan sisanya adalah supermarket," ujar Direktur Jenderal Perdagangan Dalam Negeri Kemendag, Srie Agustina di Jakarta.Industri ritel modern (modern trade) untuk kategori fast moving consumer goods (FMCG) di Indonesia tumbuh rata-rata 10,8\% pada 2015 , dengan pertumbuhan tertinggi terjadi di segmen minimarket sebesar $11 \%$ dan super/hypermarket sebesar $10,6 \%$. Penjualan toko modern per kapita di Indonesia diperkirakan mencapai US\$ 60 dengan komposisi 56\% di minimarket dan $44 \%$ di super/ hypermarket. Market size (ukuran pasar) industri minimarket di Indonesia sekitar Rp 73 triliun dengan pertumbuhan rata-rata tahunan $13,5 \%$ periode 2012 2015 (DUNIA INDUSTRI, 2016)

Tahun 2008, Aprindo Jatim mencatat total omzet retail modern di Jatim mencapai $\mathrm{Rp} 9,41$ triliun. Tahun 2009, jumlah omzet naik 20,03 persen menjadi Rp 11,49 triliun. Sedangkan tahun 2010, diprediksi peningkatan omzet berkisar 21,61 persen atau menjadi Rp 13,97 triliun. Menggiurkannya bisnis mini market itulah yang membuat pertumbuhannya makin tak terkendali, termasuk di Surabaya. Dari 346 mini market di kota ini (data versi Dinas Perdagangan dan Perindustrian Kota Surabaya), 40 persennya tidak berizin. Hal itu diakui Endang Tjaturahwati, kepala Dinas Perdagangan dan Perindustrian Kota Surabaya. Pertumbuhan fenomenal ritel modern, salah satunya diakibatkan gencarnya penetrasi ritel asing ke Indonesia. Data BisInfocus 2008 menyebutkan, jika pada 1970-1990 pemegang merek ritel asing yang masuk ke Indonesia hanya lima, dengan jumlah 275 gerai, tahun 2004 sudah 14 merek ritel asing yang masuk, dengan 500 gerai. Tahun 2008, merek ritel asing yang masuk sudah 18, dengan 532 gerai.Tahun ini, merek ritel asing yang akan melebarkan sayapnya ke Indonesia masih juga bertambah. Yang terbaru, raksasa ritel asal Korea Selatan, Lotte Mart, akan menjajal peruntungan mereka di bisnis dagangan ritel Indonesia (Amarrulah, 2010).

Surabaya merupakan salah satu pendiri pasar modern terbanyak di Indonesia. Sebagai kota terbesar kedua di Indonesia setelah Jakarta, keseharian penduduk Surabaya yang memiliki mobilitas tinggi, terkadang membuat mereka tidak sempat berbelanja bahan-bahan pokok untuk dikonsumsi setiap harinya. Oleh karena itu dengan adanya pasar modern seperti supermarket dan minimarket dapat mempermudah masyarakat untuk berbelanja kebutuhan pokok setiap harinya. Bila dibandingkan dengan pasar tradisional yang memiliki image kotor, bau, dan jam buka yang terbatas, pasar modern lebih memiliki keunggulan yang membuat masyarakat lebih memilih untuk berbelanja di supermarket ataupun minimarket terdekat. Tempat yang nyaman, dingin, bersih dan rapi, adalah kesan yang baik untuk memikat hati masyarakat.

Salah satu minimarket yang banyak jumlahnya dikawasan masyarakat Surabaya adalah Indomaret. Indomaret adalah minimarket yang dibawahi oleh PT. Indomarco Prismatama, yang menyediakan berbagai kebutuhan masyarakat, seperti kebutuhan pokok makanan, minuman, dan juga kebutuhan cuci dan kakus.Indomaret diciptakan baknya pasar modern 
dengan kesan rapi, bersih, dan nyaman. Saat ini Indomaret berkembang pesat dengan jumlah gerai mencapai lebih dari 12.800 gerai, terdiri dari $40 \%$ gerai milik terwaralaba dan $60 \%$ gerai milik perusahaan. Sesuai moto "mudah dan hemat", gerai Indomaret ditempatkan di lokasi-lokasi yang strategis, sehingga mudah dijangkau.Gerai Indomaret dengan mudah ditemukan di berbagai daerah perumahan, perkantoran, niaga, wisata, apartemen dan fasilitas umum yang terdapat di masing-masing daerah (INDOMARET, 2014).

Untuk mempertahankan beberapa keunggulan Indomaret dari minimarket lainnya dibutuhkan adanya Internal Marketing yang baik dalam suatu perusahaan. (Berry, 1981)menjelaskan Internal Marketing adalah "melihat karyawan sebagai pelanggan internal dan melihat pekerjaan sebagai produk internal". Karena karyawan adalah senjata utama untuk memenangkan hati para konsumen.Dalam mewujudkan Internal Marketing yang baik ada beberapa komponen di dalamnya yang harus dilakukan perusahaan untuk karyawannya, diantaranya adalah komunikasi, pelatihan staf, penilaian dan umpan balik dan kesadaran pelanggan.

Setelah Internal Marketing berhasil dijalankan oleh sebuah perusahaan, para konsumen dari Indomaret dan Indomaret Point memerlukan beberapa pendekatan khusus, agar terciptanya konsumen yang loyal. Dalam pembentukan konsumen yang loyal pun dibutuhkan beberapa strategi dengan menggunakan Marketing Orientation.Marketing orientation diposisikan sebagai kontribusi marketing untuk strategi bisnis (Hunt \& Lambe, 2000) dan dianggap orientasi strategis yang penting (Gatignon \& Xuereb, 1997). Indomaret dan Indomaret Point menggunakan beberapa strategi yang digunakan untuk mendekatkan diri dengan masyarakat melalui beberapa kemudahan yang bisa diakses melalui Indomaret. Beberapa program yang ditawarkan kepada para konsumennya seperti pesan antar ambil dari Indomaret, I-tiket, Ipayment, I-paket, ATM indomaret, wester union, masih banyak lagi. Untuk metode pembayarannya pun, Indomaret juga menyediakan mesin EDC, dimana konsumen bisa dapat melakukan pembayaran melalui debit ataupun kartu kredit.Indomaret dan Indomaret Point juga menyediakan kartu Indomaret bagi pelanggan setia nya, dengan adanya kartu Indomaret ini para konsumen dapat menikmati berbagai promo-promo menarik yang ditawarkan oleh Indomaret (INDOMARET, 2014).

Employee engagement yang diberikan oleh indomaret dan Indomaret Point seperti perlindungan karyawan dan, penghargaan bagi karyawan yang berprestasi. Dengan adanya Engagement tersebut, para karyawan akan termotivasi dan berloma-lomba untuk memberikan pelayanan yang terbaik untuk Indomaret, sehingga dapat terciptanya Employee Performance yang baik dari karyawan Indomaret untuk melayani konsumennya dan meningkatkan reputasi dari perusahaan.

Berdasarkan latar belakang di atas, penulis ingin melakukan penelitian yang mengangkat tema "Pengaruh Internal Marketing terhadap Employee Performance dengan Market orientation dan Employee Engagement sebagai variable perantara pada Indomaret dan Indomaret Point di Surabaya. Tujuan penelitian ini adalah untuk melihat bagaimana perusahaan mendapatkan Employee Performance melalui variable-variabel yang bersangkutan.

\section{LANDASAN TEORI}

\section{Internal Marketing}

Internal Marketing penting bagi suatu perusahaan.Internal Marketing menerapkan teori dan praktik pemasaran terhadap para karyawan.Internal Marketing awalnya diusulkan sebagai sebuah pendekatan untuk manajemen layanan yang mensyaratkan penerapan konsep pemasaran tradisional dalam organisasi dalam rangka meningkatkan efektivitas perusahaan. Oleh sebab itu, dalam suatu perusahaan perlu adanya Internal Marketing untuk meningkatkan pelayanan yang lebih baik dan lebih memuaskan sehingga komeptensi karyawan juga lebih professional dan layanan lebih efektif.

Greene (1994) mendefinisikan Internal Marketing adalah melihat karyawan sebagai pelanggan internal, pekerjaan sebagai produk internal dan berusaha untuk merancang produk ini untuk memenuhi kebutuhan pelanggan dengan lebih baik.

\section{Marketing Orientation}

Lingkungan persaingan bisnis dewasa ini semakin ketat dan banyak perusahaan perlu menyikapinya dengan sangat hati-hati agar dapat efektif dan efisien dalam mencapai penjualan yang diinginkannya.Peningkatan penjualan tidak terlepas dari bagaimana perusahaan melakukan pemasarannya.Maka dari itu, perusahaan perlu menciptakan marketing strategy agar dapat bersaing.Ada berbagai situasi ketika marketing strategy dibutuhkan seperti saat kepuasan pelanggan cenderung rendah, yang menunjukkan bahwa penyebabnya adalah sikap dan perilaku karyawan dan berbagai situasi lainnya.Dalam situasi seperti itu, kita mungkin ingin mempertimbangkan komponen-komponen internal marketing strategy 
yang salah satunya adalah internal market orientation sebagai dasar untuk sukses.

Kahn (1990) mendefinisikan Market Orientation sebagai budaya organisasi yang paling efektif dalam menciptakan perilaku penting untuk penciptaan nilai unggul bagi pembeli serta kinerja dalam bisnis.

\section{Employee Engagement}

Employee engagement adalah komitmen emosional karyawan terhadap organisasi mereka dan tindakan yang mereka ambil untuk memastikan keberhasilan organisasi.Kahn (1990) mendefinisikan Employee engagement sebagai organisasi yang memanfaatkan anggota untuk peran pekerjaan mereka, menggambarkan Employee engagement sebagai tingkat komitmen dan keterlibatan karyawan yang berdampak pada organisasi dan nilai-nilainya. Baumruk, Richman, dan Shaw mendefinisikan Employee engagement sebagai komitmen emosional dan intelektual karyawan untuk organisasi mereka.

\section{Model Penelitian}

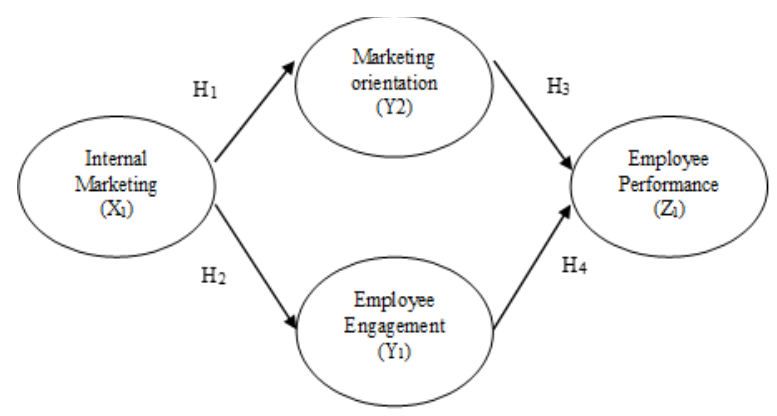

Gambar 1. Model Penelitian

\section{Hipotesa}

$\mathrm{H}_{1}$ : Internal Marketing berpengaruh terhadap Marketing Orientation

$\mathrm{H}_{2}$ : Internal Marketing berpengaruh terhadap Employee Engagement

$\mathrm{H}_{3}$ : Marketing Orientation berpengaruh terhadap Employee Performance

$\mathrm{H}_{4}$ : Employee Engagmenent berpengaruh terhadap Employee Performance

$\mathrm{H}_{5}$ : Internal Marketing berpengaruh terhadap Employee Performance

\section{METODOLOGI PENELITIAN}

\section{Populasi}

Populasi adalah gabungan seluruh elemen yang memiliki serangkaian karakteristik serupa, yang mencakup semesta untuk kepentingan masalah riset pemasaran (Malhotra, 2004). Pendapat lainnya mengatakan bahwa populasi adalah wilayah generalisasi yang terdiri dari obyek atau subyek yang mempunyai kualitas dan karakteristik tertentu yang diterapkan oleh peneliti untuk dipelajari dan kemudian ditarik kesimpulannya (Sugiyono, 2009). Populasi dalam penelitian ini adalah karyawan dari Indomaret dan Indomaret Point di Surabaya.

\section{Sampel}

Sampel adalah sebagian dari populasi yang ditetapkan oleh peneliti (Sugiyono, 2009). Malhotra (2007) juga menambahkan bahwa sampel adalah kelompok dari unsur-unsur populasi yang dipilih untuk berpartisipasi dalam penelitian. Dalam melakukan survei tidak perlu untuk meneliti semua individu dalam populasi karena akan banyak biaya dan waktu. Namun, syarat utama sampel yang baik yaitu apabila sampel yang diambil mewakili ciri dan karakteristik populasi (representatif) dengan bias yang kecil (Sugiyono, 2009).

\section{Definisi Operasional Variabel}

1. Internal Marketing (X1)

a. Employee Motivation and Satisfaction Diyakini bahwa perusahaan harus memiliki karyawan yang puas untuk memiliki pelanggan yang puas, karena pelayanan langsung kepada pelanggan dilakukan oleh tenaga kerja.

b. Customer Orientation

Hal ini diyakini bahwa customer orientation yang akan menciptakan kepuasan pelanggan eksternal, yang merupakan cara untuk menawarkan service excellence.

c. Strategy Implementation and Change Management

Internal Marketing juga berbicara mengenai usaha untuk mengatasi permasalahan organisasional untuk berubah dan untuk meluruskan, memotivasi, dan mengintegrasi karyawan menuju implementasi perusahaan dan strategi fungsional yang efektif.

2. Marketing Orientation (Y1)

a. Customer Orientation

Strategi bisnis dalam model bisnis yang mengharuskan manajemen dan karyawan untuk fokus pada perubahan keinginan dan kebutuhan pelanggannya.

b. Competitor Orientation

Ketika sebuah bisnis berorientasi pada persaingan, bisnis itu terus menilai kembali kekuatan dan kelemahannya terhadap pesaingnya.Evaluasi kinerja dapat mencakup efisiensi produksi, penetapan harga, waktu pengiriman, kepuasan pelanggan, inovasi, retensi karyawan dan pangsa pasar. 
c. Interfunctional Coordination

Didefinisikan sebagai kerja sama berbagai fungsi bisnis internal untuk mencapai tujuan keseluruhan perusahaan dan memastikan responsif terhadap perubahan lingkungan.

3. Employee Engagement (Y2)

a. Intellectual Engagement

Berpikir keras tentang pekerjaan dan bagaimana melakukannya dengan lebih baik.

b. Affective engagement

Merasa positif tentang melakukan pekerjaan yang baik.

c. Social engagement

Aktif mengambil kesempatan untuk membahas perbaikan pekerjaan yang berhubungan dengan orang lain di tempat kerja.

4. Employee Performance (Z1)

a. Task Performance

Task Performance dapat diartikan sebagai keefektifan kerja dalam melakukan kegiatan yang berkontribusi terhadap inti teknis organisasi secara langsung dengan menerapkan sebagian dari proses teknologinya, atau secara tidak langsung dengan menyediakannya melalui bahan atau layanan yang dibutuhkan. Contoh aktifitasnya seperti Pengetahuan Produk, Penutupan Penjualan, dan Organisasi dan Manajemen Waktu.

b. Contextual Performance

Contextual Performance penting karena berkontribusi pada efektifitas organisasi dengan cara yang membentuk organisasi, sosial, dan psikologis konteks yang berfungsi sebagai katalisator untuk kegiatan dan proses tugas. Kegiatan kontekstual melakukan kegiatan yang tidak secara formal dilakukan dalam pekerjaan dan membantu dan bekerja sama dengan orang lain dalam organisasi untuk mendapatkan task accomplished.

\section{ALAT ANALISA}

\section{Path Analysis}

Pengujian hipotesis yang ada pada penelitian ini dilakukan dengan menggunakan teknik path analysis untuk menujukkan adanya hubungan yang kuat dengan variabel-variabel yang diuji.Teknik path analysis digunakan untuk melukiskan dan menguji model hubungan antar variabel yang berbentuk sebab akibat (Sugiyono, 2007).Teknik ini merupakan pengembangan korelasi yang diurai menjadi beberapa interpretasi akibat yang ditimbulkannya.

Pengujuan statistik pada model path analysis dilakukan dengan menggunakan metode partial least square.Partial Least Square (PLS) adalah bagian dari
SEM. PLS merupakan teknik terbaru yang banyak diminati karena tidak membutuhkan distribusi normal atau dapat dikatakan sebuah penelitian dengan jumlah sampel yang sedikit. Salah satu kelebihan PLS-SEM adalah mampu menangani model yang kompleks dengan multiple variabel eksogen dan endogen dengan banyak indikator, dapat digunakan pada sampel dengan jumlah kecil, dan data distribusi yang condong (Abdillah \& Hartono, 2015).

\section{T-test}

Di dalam penelitian ini terdapat variabel intervening yaitu penghubung antara variabel dependen dan variabel independen. Pengujian hipotesis mediasi (variabel intervening) dapat dilakukan dengan prosedur $t$-test. Pengujian $t$-test digunakan untuk mendapatkan nilai t-statistik yang diperlukan apabila peneliti ingin melakukan uji hipotesis, sehingga peneliti dapat mengatakan pengaruh sebuah variabel dapat dikatakan memiliki pengaruh yang signifikan atau tidak.Ttest dilakukan dengan menggunakan metode bootstrapping.

Metode bootstrappingadalah suatu proses pengujian re-samplingyang dilakukan oleh sistem komputer untuk mengukur akurasi pada sampleestimate. Bootstraping digunakan untuk mengukur akurasi pada sample. Apabila nilai bootstrap lebih dari (>) 1.96 maka dinyatakan bahwa variabel tersebut memiliki pengaruh yang signifikan sedangkan apabila nilai bootstrap lebih rendah $(<)$ dari 1.96 , maka dinyatakan pengaruh variabel tersebut lemah (Abdillah \& Hartono, 2015).

\section{Statistik deskriptif}

Statistik deskriptif digunakan untuk menyajikan data secara deskriptif yang menggambarkan karakteristik responden serta jawaban-jawaban responden sehingga mampu digunakan sebagai kesimpulan dari hasil kuisioner yang sudah disebarkan selama penelitian ini.

\section{ANALISA DAN PEMBAHASAN}

\section{Analisa Deskriptif}

Employee Motivation and Satisfaction mencerminkan kemampuan Indomaret untuk memberi dukungan berupa motivasi agar para karyawannya dapat merasa puas bekerja di Indomaret, sehingga mereka dapat menerapkannya kepada konsumen.

Customer Orientation menunjukkan kemampuan dari Indomaret dalam mengembangkan psikis dan 
mental para karyawannya. Indomaret memandang bahwa para karyawan adalah konsumen internalnya, sehingga Indomaret akan memuaskan konsumen internalnya terlebih dahulu agar mereka dapat mengimplementasikan hal tersebut kepada konsumen eksternal. Oleh karena itu Indomaret memberikan para karyawannya pelayanan yang terbaik pula untuk memuaskan hati mereka baknya konsumennya sendiri.

Kedua hal tersebut dapat dilihat dari pelayanan yang konsisten dari Indomaret yang selalu memberikan salam dan sapa kepada setiap konsumen yang datang ke Indomaret. Hal ini tercipta dari evaluasi ataupun masukan dari para konsumen sebelumnya, agar terciptanya suasana yang akrab antara Indomaret dengan para konsumen sehingga para konsumen akan loyal dan senang berbelanja di Indomaret.

Strategy Implementation and Change Management merupakan kemampuan Indomaret untuk mengatur seluruh strategi dan akan diinformasikan kepada seluruh karyawannya disesuaikan dengan berbagai jobdesc masing masing karyawan, sehingga bisa sampai kepada pelanggan.

Indomaret setiap tahunnya selalu berupaya untuk meningkatkan kualitas maupun layanan untuk mendekatkan diri dari konsumennya.

Customer orientation merupakan suatu strategi dari Indomaret untuk mendekatkan diri kepada konsumennya melalui kinerja para karyawan dapat menjalin hubungan yang baik dengan para konsumen yaitu melayani dengan ramah seperti memberikan keranjang untuk para konsumen yang baru datang, memberikan salam sapa seperti "selamat datang di Indomaret, selamat belanja" dan juga memberikan informasi terkait beberapa promo yang ada di Indomaret saat ini. Beberapa bentuk strategi pendekatan terhadap konsumen tersebut mampu meningkatkan loyalitas dari konsumen Indomaret.

Competitor Orientation merupakan tahapan Indomaret dalam mengenali para pesaingnya. Dari Interfunctional Coordination memiliki arti bahwa karyawan ikut berpartisipasi dalam meningkatkan kualitas mutu Indomaret melalui kinerja masingmasing jobdesc untuk memberikan nilai lebih kepada konsumen Indomaret.

Intelectual Engagement yaitu tingkat kesatuan yang dimiliki oleh karyawan terhadap Indomaret, sejauh apa karyawan merasa perusahaan menjadi bagian dalam dirinya dan mereka ingin berusaha keras untuk selalu meningkatkan kualitas dari Indomaret.

Affective Engagement merupakan keadaan psikologis yang mempengaruhi karyawan terhadap Indomaret, dimana para karyawan akan merasakan suasana yang positif ketika mereka mengerjakan pekerjaannya dengan baik. Pada

Social Engagement merupakan keadaan dimana antara karyawan dan atasan berkumpul untuk pembahasan mengenai perbaikan Indomaret secara rutin.

Task Performance merupakan sebuah komitmen dari karyawan kepada Indomaret. Dalam hal ini menyatakan bahwa perusahaan indomaret mampu memberikan yang terbaik kepada karyawannya sehingga para karyawan juga akan berupaya memberikan yang terbaik pula bagi Indomaret yang berpegang pada tanggung jawab dari setiap individu yang bekerja di Indomaret.

\section{Indikator}

Contextual Performance merupakan suatu kinerja yang tercipta karena adanya kerjasama antara satu karyawan dengan karyawan lainnya untuk menghasilkan sesuatu demi kepentingan bersama yaitu kemajuan dari indomaret. Indomaret juga mampu membetuk suasana kerja seperti keluarga antara karyawan satu dengan lainnnya.

Employee performance di Indomaret menunjukkan bahwa Indomaret memiliki karyawan yang cukup baik dalam hal kerjasama, taat akan peraturan, bertanggungjawab dan tentunya semua ini adalah sarana awal keunggulan bersaing dari para pesaingnya melalui kinerja yang baik dari para karyawan dan staffnya.

\section{Evaluasi Path Coefficient dan Coefficient of determination}

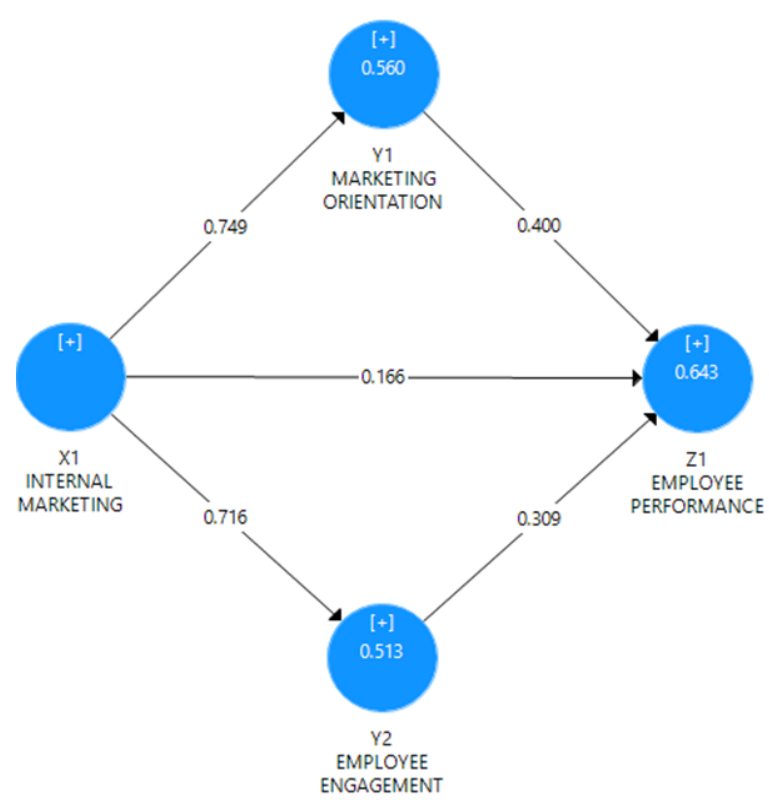

Gambar 2. Path Coefficient dan Coefficient of determination 
Pada analisa path coefficient ini telah dibuktikan bahwa Marketing orientation dan Employee Engagement merupakan variabel intervening dimana memperkuat hubungan antara Internal Marketing dan Employee Performance. Dari gambar diatas dapat dijelaskan bahwa nilai path coefficient terbesar ditunjukkan dari pengaruh Internal Marketing terhadap Marketing Orientation sebesar 0,749.Sedangkan kontribusi nilai Internal Marketing terhadap Employee Engagement sebesar 0,716. Dalam gambar di atas pengaruh Internal Marketing ke Marketing Orientation dan Employee Engagement tidak terpaut jauh nilai path coefficientnya sehingga, hubungan menuju Employee Performance terkuat juga didapat ketika Internal Marketing melewati Marketing Orientation dan Employee Engagement menuju Employee Performance.

Pada hubungan Internal Marketing terhadap Employee performance secara langsung memiliki path coefficient senilai 0,166. Lalu ketika hubungan tersebut melalui variabel Marketing Orientation terlebih dahulu, maka nilai dari path coefficient meningkat menjadi $0,2996(=0,749 \times 0,400)$. Sehingga hal ini merupakan bukti bahwa Marketing Orientation merupakan variabel intervening yang memperkuat hubungan antara Internal Marketing dengan Employee Performance.

Selain Marketing Orientation, Employee Engagement juga memiliki peranan sebagai variabel intervening dimana memperkuat hubungan antara Internal Marketing dengan Employee Performance. Diketahui bahwa nilai path coefficient dari hubungan Internal Marketing dengan Employee Performance sebesar 0,166. Lalu ketika hubungan tersebut melalui variabel Employee Engagement maka nilai tersebut meningkat menjadi $0,221(=0,716 \times 0,309)$. Sehingga dari hal tersebut menjadi bukti bahwa Employee Engagement sebagai variabel intervening memperkuat hubungan yang sudah ada.

Jadi kesimpulan bagi seluruh variabel dalam model ini memiliki path coefficient dengan angka yang positif.Artinya, jika semakin besar nilai path coefficient pada satu variabel independen terhadap variabel dependen, maka semakin kuat juga pengaruh antara variabel independen terhadap variabel dependen tersebut. Namun hubungan Internal Marketing terhadap Employee Performance secara langsung memiliki angka yang paling rendah, yaitu 0,166 yang berarti pengaruh Internal Marketing terhadap Employee performance sangatlah rendah.

\section{T-statistic}

Tabel 1.T-statistic

\begin{tabular}{|c|c|c|c|c|}
\hline & $\begin{array}{c}\text { Original } \\
\text { Sample } \\
\text { (O) }\end{array}$ & $\begin{array}{l}\text { Sample } \\
\text { Mean } \\
\text { (M) }\end{array}$ & $\begin{array}{l}\text { Standard } \\
\text { Error } \\
\text { (STERR) }\end{array}$ & $\begin{array}{c}\text { T statistics } \\
(|\mathrm{O} / \mathrm{STDEV}|)\end{array}$ \\
\hline $\begin{array}{l}\mathrm{MM}(\mathrm{X} 1)-> \\
\mathrm{MO}(\mathrm{Y} 1)\end{array}$ & 0,749 & 0,756 & 0,053 & 14,062 \\
\hline $\begin{array}{l}\mathrm{IM}(\mathrm{X} 1)->\mathrm{EE} \\
(\mathrm{Y} 2)\end{array}$ & 0,716 & 0,727 & 0,051 & 13,967 \\
\hline $\begin{array}{l}\mathrm{IM}(\mathrm{X} 1)->\mathrm{EP} \\
(\mathrm{Z} 1)\end{array}$ & 0,166 & 0,154 & 0,111 & 1,499 \\
\hline $\begin{array}{l}\mathrm{MO}(\mathrm{Y} 1)->\mathrm{EP} \\
(\mathrm{Z} 1)\end{array}$ & 0,400 & 0,400 & 0,097 & 4,115 \\
\hline $\begin{array}{l}\mathrm{EE}(\mathrm{Y} 2)->\mathrm{EP} \\
(\mathrm{Z} 1)\end{array}$ & 0,309 & 0,323 & 0,120 & 2,571 \\
\hline
\end{tabular}

Dengan melihat Tabel 1, dapat diartikan bahwa nilai original sample $(\mathrm{O})$ adalah nilai path coefficient yang menunjukkan kekuatan pengaruh dari satu latent variable ke satu latent variable lainnya. Sedangkan nilai pada kolom sample mean (M) menunjukkan nilai tengah dari path coefficient. Sedangkan standard error (STDERR), menunjukkan nilai error pada sampel mean. Nilai $\mathrm{T}$ statistics untuk melihat nilai $\mathrm{T}$ hitung yang akan digunakan untuk pengujian hipotesis, dimana $\mathrm{T}$ statistics yang

Pengaruh Internal Marketing terhadap Marketing Orientation memiliki nilai T-statistics 14,062, artinya terdapat pengaruh dari Internal Marketing terhadap Marketing Orientation.Pengaruh Internal Marketing terhadap Employee Engagement memiliki nilai T-statistics 13,967 , artinya terdapat pengaruh dari Internal Marketing terhadap Employee Engagement.Pengaruh Internal Marketing terhadap Employee Performance memiliki nilai T-statistics 1,499, artinya tidak terdapat pengaruh dari Internal Marketing terhadap Employee Performance.Pengaruh Marketing Orientation terhadap Employee Performance memiliki nilai T-statistics 4,115, artinya terdapat pengaruh Marketing Orientation terhadap Employee Performance.Pengaruh Employee Engagement terhadap Employee Performance memiliki nilai T-statistics 2,571, artinya terdapat pengaruh dari Employee Engagement terhadap Employee Performance.

\section{PEMBAHASAN}

\section{Internal Marketing to Marketing Orientation}

Hasil penelitian ini menunjukkan bahwa variabel Internal Marketing dari Indomaret memiliki pengaruh yang positif terhadap Marketing Orientation dengan hasil nilai uji T-statistics > 1,96 yaitu sebesar 14,062 . 
Langkah awal yang Indomaret lakukan dalam perusahaannya adalah menganggap bahwa setiap karyawannya adalah pelanggan internalnya, sehingga para karyawan akan merasa diperhatikan layaknya pelanggan dari Indomaret sendiri. Hasil kepuasan dari karyawan tersebut akan memberikan feedback positif juga bagi Indomaret. Untuk mencapai tujuan utama dari Indomaret menjadi market leader pada mini market di Indonesia ini, membutuhkan beberapa dukungan upaya dari para karyawannya, oleh karena itu Indomaret berusaha untuk memperlakukan para karyawannya dengan baik. Karyawan Indomaret secara keseluruhan menilai bahwa Indomaret telah mampu menciptakan Internal Marketing yang baik, sehingga para karyawan merasa puas, nyaman dan senang bekerjasama dengan Indomaret untuk mencapai tujuan yaitu menjadi market leader pada mini market terkhususnya di Indonesia.

\section{Marketing Orientation terhadap Employee Perfor- mance}

Nilai Marketing Orientation terhadap Employee Performance pada Indomaret memiliki nilai T-Statistic di atas 1,96, yaitu 4,115. Nilai ini menunjukkan bahwa hubungan antara Marketing Orientation dan Employee performance memiliki nilai yang signifikan.

Markerting Orientation merupakan strategi yang dibentuk Indomaret untuk meraih tujuan utamanya melalui bantuan para karyawannya.Pembentukan strategi ini dipersepsikan oleh karyawan sudah terbentuk dengan baik. Dari adanya pemahaman strategi memenangkan hati konsumen, memahami pesaing dari indomaret dan juga bekerja secara efektif dan efisien, karyawan akan mencoba melakukan strategi tersebut dengan baik secara terus menerus hingga akhirnya timbul aktivitas yang dapat membuat tujuan perusahaan berhasil.

Nilai path coefficient dari Marketing orientation terhadap Employee Performance adalah 0,400. Nilai ini menunjukkan adanya pengaruh yang cukup kuat dari Marketing Orientation terhadap Employee Performance. Karyawan Indomaret yang puas akan perusahaan akan membantu perusahaan untuk menciptakan strategi demi mencapai tujuan bersama. Dengan kata lain perusahaan memiliki peluang yang sangat besar untuk memiliki komitmen jangka panjang dengan karyawannya dengan menjadi seorang internal customer yang loyal pada perusahaan Indomaret.

\section{Employee Engagement terhadap Employee Perfor- mance}

Dari hasil analisa penelitian ini juga dapat dibuktikan bahwa Employee Engagement memiliki pengaruh terhadap Employee Performance.Pada hubungan ini, Employee performance atau kinerja karyawan timbul disebabkan hasil dari motivasi dan keterikatan yang sudah terbentuk dengan membandingkan nilai yang ditawarkan perusahaan dibanding pesaing lainnya. Jadi karyawan akan terus termotivasi untuk meningkatkan kualitas produk dan layanan Indomaret selama mereka mendapatkan dukungan dan motivasi dari Indomaret dengan berbagai macam apresiasi dan penghargaan bagi karyawan yang ikut andil dalam mengembangkan Indomaret. Pada hasil penelitian ini ditemukan bahwa pengaruh tersebut merupakan hasil uji T-statistics dengan nilai 2,571, yaitu diatas 1,96. Sehingga diketahui bahwa Employee Engagement mempengaruhi kinerja karyawan pada Indomaret.

Selain itu apabila dilihat dari nilai path coeficient, hubungan dari Employee Engagement menuju Employee Performance sebesar 0,309.Pengaruh Employee Engagement kepada Employee Performance lebih besar daripada Internal Marketing secara langsung.Keunggulan yang dimiliki oleh Indomaret mampu memberikan daya tarik bagi karyawan yang termotivasi untuk melakukan sesuatu hal yang positif untuk kemajuan dari Indomaret.

\section{Internal Marketing to Employee Performance}

Pada hasil penelitian ini dapat dilihat bahwa Internal Marketing tidak hanya memiliki pengaruh yang pada Marketing Orientation, namun berpengaruh pula pada Employee Engagement dari Indomaret dengan nilai uji T-statistics $>1,96$ yaitu 13,967. Hasil tersebut membuktikan bahwa Internal Marketing memiliki dampak signifikan dalam membangun engagement antara perusahaan dan karyawannya.

Internal Marketing yang menjadi bagian utama dari Indomaret yang memerlukan pendekatan khusus kepada karyawannya dalam memberikan suatu motivasi yang mengikat, supaya para karyawan dapat merasa bahwa perusahaan peduli akan hasil yang mereka capai demi kemajuan dari Indomaret. Kemampuan perusahaan dalam memotivasi karyawan sangat penting guna memberikan semangat agar kinerja para karyawan selalu baik dan konsisten, tidak merasa jenuh akan dunia kerja melainkan memberikan suatu apresiasi pada karyawan yang berprestasi.

Secara keseluruhan pembahasan hipotesis diatas mampu menjawab rumusan masalah pada penelitian ini.Hubungan antar konsep dapat diterima dengan diperkuat oleh data hasil observasi.Keseluruhan variabel memiliki hubungan signifikan kecuali hubungan langsung Internal Marketing terhadap Employee Performance.Hal ini membuktikan bahwa 
Marketing Orientation dan Employee Engagement sudah menjadi variabel dengan nilai invervening sempurna dalam bidang mini market ini untuk bisa menciptakan kinerja karyawan yang positif untuk mencapai tujuan Indomaret.

\section{KESIMPULAN DAN SARAN}

Dari seluruh pembahasan dalam penelitian ini, maka dapat disimpulkan bahwa Internal Marketing merupakan kemampuan penting yang harus dimiliki oleh Indomaret untuk terus berkembang dan bisa menghadapi persaingan dalam industry mini market. Hal ini dibuktikan dalam penghitungan statistik bahwa implementasi Internal Marketing berpengaruh positif terdahap Marketing Orientation dan Employee Engagement serta variabel - variabel tersebut yang berperan penting dalam menciptakan Employee Performance.

Oleh karena itu indomaret dan Indomaret Point, harus lebih meningkatkan Internal Marketing agar terciptanya suatu hubungan yang lebih baik antara perusahaan dan karyawan.Tidak hanya sebatas meningkatkan hubungan baik, namun perlu ditambahkan sesuatu yang mengikat karyawan seperti penghargaan, apresiasi, kenaikan pangkat, dan peningkatan gaju untuk para karyawan yang berprestasi. Apabila karyawan merasa nyaman dengan Indomaret dan Indomaret Point, maka mereka akan berusaha semaksimal mungkin untuk meningkatkan kinerja mereka demi mendukung kemajuan dari perusahaan.

\section{DAFTAR PUSTAKA}

Abdillah, W., \&amp; Hartono, J. (2015).Partial Least Square (PLS) Alternatif Stuctural Equation Modeling (SEM) dalam Penelitian Bisnis (Cetakan 1). Yogyakarta: Penerbit Andy.

Amarrulah, A. (2010, Mei 24). nasional.news.viva. co.id.Retrieved from http://nasional.news.viva. co.id/news/read/153146-ritel-modern-surabayatak-terkendali: http://nasional.news.viva.co.id

Baskoro, F. M. (2016, Juni 7). beritasatu.com. Retrieved from http://www.beritasatu.com/ekonomi/368786-indonesia-masuk-lima-besar-sektorritel-paling-potensial-di-dunia.html: http://beritasatu.com.
Dahwilani, D. M. (2015, juni 2).sindonews. Retrieved from https://ekbis.sindonews.com/read/1007773/ 34/pertumbuhan-ritel-indonesia-peringkat-12dunia-1433163799: http://sindonews.com

DUNIA INDUSTRI. (2016, Januari 5). duniaindustri. com. Retrieved from http://duniaindustri.com/ downloads/data-industri-minimarket-supermarkethypermarket-di-indonesia/:http://duniaindustri. com

Gatignon, H., \& Xuereb, J.-M.(1997). Strategic Orientation of the Firm and New Product performance.Journal of Marketing Research, 34, 77-90.

Greene, W.E., G.D. Walls and L.J. Schrest, 1994. Internal marketing: The key to external marketing success. J. Services Market. 8: 5-13.

Hunt, S. D., \& Lambe, C. J. (2000). "Marketing's contribution to business strategy: market orientation, relationship marketing and resourceadvantage theory". International Journal of Management Reviews, 2(1), pp, 17-43.

INDOMARET.(2014). indomaret.co.id. Retrieved fromhttps://indomaret.co.id/korporat/seputarindomaret/peduli-dan-berbagi/2014/01/16/geraiindomaret/: http://indomaret.co.id

Kahn, W.A. (1990). Psychological conditions of personal engagement and disengagement at work, Academy of Management Journal, 33, 692-724

Maskur, F. (2016, june 6). industri.bisnis.com. Retrieved from http://industri.bisnis.com/read/ 20160606/100/555024/ritel-indonesia-tumbuhangka-penjualan-capai-us324-miliar:http://industri. bisnis.com

Malhotra, N. K. (2004). Marketing research: an applied orientation (4th Editio). New Jersey: Upper Saddle River. . (2007). Marketing Research, an Applied Orientation. New Jersey: Pearson Education.

Sugiyono.(2007). Statistika untuk penelitian (Cetakan 10). Bandung: Alfabeta.

----, (2009). Metode penelitian bisnis: Pendekatan kuantitatif, kualitatif, dan R \&amp; D (Cetakan 14). Bandung: Alfabeta. 